\title{
Nasopharyngeal Carcinoma Associated with Lassa Fever Virus Infection \\ Obasikene $\mathrm{G}^{1 *}$, Kpolugbo $\mathrm{J}^{2}$, Ibiam FA ${ }^{3}$, Adobamen $\mathrm{PROC}^{4}$, Esezebor $\mathrm{E}^{2}$, Tobin Ek ${ }^{5}$, Asogun DA ${ }^{5}$, Obasikene $\mathrm{CN}^{6}$, Saiki BO${ }^{1}, \mathrm{Ayeke}^{\mathrm{J}}{ }^{1}$ and Agbonifo $\mathbf{M}^{1}$ \\ ${ }^{1}$ ENT Unit, Irrua Specialist Teaching Hopsital, Irrua, Nigeria
}

${ }^{2}$ Department of Surgery, Irrua Specialist Teaching Hopsital, Irrua, Nigeria

${ }^{3}$ Ear, Nose and Throat unit, Federal Medical Center Owerri, Imo State South East Nigeria, Nigeria

${ }^{4}$ Department of Oto-Rhino-Laryngology, University of Benin Teaching Hospital, Benin City, Nigeria

${ }^{5}$ Institute of Lassa Fever Research and Control, Irrua Specialist Teaching Hospital, Irrua, Nigeria

${ }^{6}$ Department of Radiology, University of Benin Teaching Hospital, Benin City, Nigeria

\begin{abstract}
Nasopharyngeal carcinoma (NPC) is a head and neck cancer usually found in the nasopharynx and arising mostly from Fossa Rosenmueller. The aetiopathogenesis has been linked to environmental factors, genetic susceptibility and Epstein-Barr virus infection. However, more recent data state that all the three subtypes of NPC tumors are associated to Epstein-Barr virus infection (EBV). Therefore we present cases of NPCs associated to Lassa fever virus infection. Lassa fever virus is a member of the arena viridae group. It is endemic in Edo state, which accounts for the highest number of cases of the disease in the country. Despite the magnitude of the mortality rate of this disease in Edo land, not much has been done by any institute to assess the long time effect of the disease on the endemic communities. We hence present two known cases of NPC in two confirmed cases of Lassa fever virus patients some years prior to the diagnoses of the NPC.
\end{abstract}

Keywords: NPC; Lassa fever virus

\section{Introduction}

Nasopharyngeal carcinoma (NPC) is a head and neck cancer usually found in the nasopharynx and arising mostly from fossa rosenmueller. Its incidence and geographical distribution depends on several factors such as genetic susceptibility, environment, and personal habits. Faradel in 1837 was first to report the finding of malignant tumours of nasopharynx at autopsy although the diagnosis was not supported by histological evidence of the neoplasm. NPC is associated with Epstein-Barr virus (EBV) [1]. It is seen almost all-over the world but common in certain geographic areas, such as southern Asia [2,3]. The aetiopathogenesis is multifactorial, environmental factors and genetic susceptibility has been documented to be of great importance roles in NPC pathogenesis, Epstein-Barr virus is also implicated in the molecular abnormalities leading to NPC [4].

The World Health Organization classifies NPC based on histological type [5]. The keratinizing squamous cell carcinoma which is characterized by well-differentiated cells that produces keratin is Type I. The "Type II" is non-keratinizing squamous carcinoma; it varies in cell differentiation but does not produce keratin. "Type III" is, undifferentiated carcinoma. It constitute about $60 \%$ of NPC, and majority of it is found in young patients, It is difficult to differentiate it from lymphoma by light microscopy and it requires special stains \& markers. It has diverse groups which include lymphoepitheliomas, spindle cell, clear cell and anaplastic variants. Both Types 2 and 3 NPC associated are Epstein-Barr virus (EBV). However, more recent data state that almost all NPC tumors, regardless of histologic subtype, have comorbid EBV infections, which is strong evidence for EBV as the etiology of NPC [6].

In this report we present Lassa fever virus implicated in patients with NPC. Lassa fever is caused by the Lassa virus, a member of the arena viridae group. The incubation period of the disease is 6 to 21 days; early symptoms mimicking a wide variety of febrile illness found in the tropics. All ages and sexes are affected by the disease.

While the mortality rate of this virus is not as high as with some viral hemorrhagic fevers, there are many more cases of Lassa fever, and a great number of survivors permanently affected by the complications of the disease. Lassa fever is endemic in Edo state, which accounts for the highest number of cases of the disease in the country. Despite the magnitude of the disease in the state relative to the rest of the country, little has been done by any institution to assess the burden of the disease in the endemic communities.

We present two known cases of NPC diagnosed in patients who suffered Lassa fever some years prior to the diagnoses of their NPC. Both patients also tested positive for high titre of specific antibody to Lassa as at the time of the NPC hitological diagnosis.

\section{First case report}

The patient is Mrs L.U a 28 year female trader. She is a Christian and Esan by tribe in Edo state. She presented to Ear, Nose and Throat clinic (ENT) of Irrua Specialist Teaching Hospital (ISTH) with 4 months history of right sided neck swelling and 1 month left sided neck swelling. The swelling was first noticed on the right and later the left side got involved. Initially it was small, almost the size of her thumb. It was painless, not discharging and same colour with the surrounding skin. The swelling was progressively increasing in size. She noticed a similar swelling in the left side of the neck 3 months later which took the same pattern like the right neck swelling. There was no associated dysphagia, odynophagia, dyspnoea, dysphonia anorexia, and no weight loss. She had one episode of epistaxis that stopped on its own 3 months ago but no other associated nasal symptoms. She did not have any ear and eye symptoms. She was treated for Lassa fever virus infection in

*Corresponding author: Obasikene G, ENT Unit, Irrua Specialist Teaching Hopsital, Irrua, Tel: +234(8)37029753; E-mail: godwinkate@yahoo.co.uk

Received December 09, 2013; Accepted February 18, 2014; Published February 25,2014

Citation: Obasikene G, Kpolugbo J, Ibiam FA, Adobamen PROC, Esezebor E, et al. (2014) Nasopharyngeal Carcinoma Associated with Lassa Fever Virus Infection. J Health Med Informat 5: 147. doi:10.4172/2157-7420.1000147

Copyright: (c) 2014 Obasikene G, et al. This is an open-access article distributed under the terms of the Creative Commons Attribution License, which permits unrestricted use, distribution, and reproduction in any medium, provided the original author and source are credited. 
2009. At the time of presentation she was breast feeding her 3rd baby of 3 month old.

Clinical examination showed a lactating young woman. She was not fibrile, not pale, anicteric and acyanosed. The vital signs were normal. There were bilateral neck swellings at level II and III cervical lymph node zones. The right swelling was measuring $6 \times 4 \mathrm{~cm}$, while the left measured $4 \times 4 \mathrm{~cm}$ both were firm, not tender, not fluctuant and not attached to overlying skin. The ears, eyes and the nose were essentially normal. She did a CT-scan of head and neck which was essentially normal. She was worked up for examination under anaesthesia and biopsy of the nasopharynx. The complete blood count, serum electrolyte, urea and creatinine were normal.

Operation findings showed an infiltrative mass obliterating the nasopharynx. Histology report revealed differentiated keratinizing squamous cell carcinoma of the nasopharynx. Patient was subsequently referred for radiotherapy and she is currently responding well to treatment. The patient was also screened for specific antibody for Lassa fever virus and the result showed a positive high titre value of specific antibody to Lassa fever virus.

\section{Second case report}

The patient was a 17 years old girl. She is a Christian and Esan by tribe in Edo State and also resides in Esan land. She presented to ENT clinic of ISTH with 6 months history of unilateral right sided neck swelling. The swelling was initially small, almost the size of her thumb. It was not painful, not discharging and was of the same colour with the surrounding skin. The swelling was progressively increasing in size. There was no associated dysphagia, dysphagia, dyspnoea, dysphonia anorexia, and no weight loss. No associated nasal symptoms. She did not have any ear and eye symptoms. Her younger brother that was living in the same house with her was diagnosed and treated for Lassa fever virus infection in 2008.

Clinical examination showed that she was not febrile, not pale, anicteric and acyanosed. The vital signs were normal. There were about 3 right neck swellings that was at level II and III cervical lymph node zones, all were matted together. The biggest measuring $8 \times 7 \mathrm{~cm}$ and located at upper jugulodigastric, while the remaining two measured $4 \times 4 \mathrm{~cm}$ both were firm, non tender, non fluctuant and not attached to overlying skin. The ears, eyes and the nose were essentially normal. She was worked up for examination under anaesthesia and biopsy of the nasopharynx. The complete blood count, serum electrolyte, urea and creatinine were normal. Operation findings showed an infiltrative mass obliterating the nasopharynx. Histology report revealed differentiated squamous cell carcinoma of the nasopharynx. Patient was subsequently referred for radiotherapy and she is currently doing well.

Patient was also screened for specific antibody to Lassa fever virus and the result showed a positive high titre value of specific antibody to Lassa fever virus.

\section{Discussion}

This case report is being presented because there has not been any documented case of similar close association between NPC in the past. Also, there has been a rising incidence of NPC and Epithelia Neoplasm in the geographical areas of Lassa fever virus infection. The number of NPC seen in our ENT clinic has risen to about 4 cases within one month in some seasons. Our obstetrics and gynecology clinic has equally documented the flooding of their clinic with carcinoma of the cervix which is the commonest gynecological malignancy in Edo state [6]. This NPC has been observed both in the young, young adult and middle aged patient especially in women. We hardly use to take history of Lassa fever infection nor even screen for the Lassa fever specific antibody in patients with NPC. The moment we got the past medical history of Lassa in one person we decided to add it to part of the history for every NPC patient and also to screen for the specific antibody to Lassa fever infection. This was how we were able to discover history of Lassa fever virus infection in the second case report.

"The issue of neoplasm being associated with Lassa virus is a cause for alarm and I think that Lassa virus infection is more dangerous than nuclear weapon"

Just like EBV infection is known to be implicated in most epithelia neoplasm [7]. One may have to know if Lassa fever virus is also implicated in the Carcinoma of the cervix which is the most common malignancy among women in this Lassa endemic community $[8,9]$.

Lassa fever virus and Epstein-Barr virus belong to the different family of Virus. LMP1 has been found to be the principal oncogene of NPC-as it is required for cell immortalization and also been documented to be present in $80 \%$ to $90 \%$ of NPC tumors [10]. However none of these researches has been elaborated in Lassa fever virus infected patient or even in this part of the globe. There is a need for tumorigenesis in NPC in the Lassa fever endemic community. If 95\% of NPCs is associated with Epstein-Barr virus; then it could be that there is a suffered infection of Epstein-Barr virus on post-Lassa fever virus infected patients with high titre level of specific antibody to Lassa fever virus [11]. If all NPCs are to be associated with Epstein-Barr virus then it could be that Lassa fever virus infection increases the chances of the Epstein-Barr virus causing NPC, peradventure that the affected individuals had Epstein-Barr virus infection earlier in their life time [6].

\section{References}

1. Marks JE, Phillips JL, Menck HR (1998) The National Cancer Data Base report on the relationship of race and national origin to the histology of nasopharyngeal carcinoma. Cancer 83: 582-588.

2. Parkin DM, Muir CS (1992) Cancer incidence in five continents. Comparability and quality of data. IARC Sci Publ 120: 45-173.

3. Nielsen NH, Mikkelsen F, Hansen JP (1977) Nasopharyngeal cancer in Greenland. The incidence in an Arctic Eskimo population. Acta Pathol Microbiol Sc and $[A]$ 85: 850-858.

4. Yu MC, Ho JH, Ross RK, Henderson BE (1981) Nasopharyngeal carcinoma in Chinese-salted fish or inhaled smoke? Prev Med 10: 15-24.

5. Shanmugaratnam K, Sobin L (1991) Histologic typing of tumours of the upper respiratory tract and ear. 2 Geneva, WHO.

6. Vasef MA, Ferlito A, Weiss LM (1997) Nasopharyngeal carcinoma, with emphasis on its relationship to Epstein-Barr virus. Ann Otol Rhinol Laryngol 106: 348-356.

7. Pathmanathan R, Prasad U, Sadler R, Flynn K, Raab-Traub N (1995) Clona proliferations of cells infected with Epstein-Barr virus in pre-invasive lesions related to nasopharyngeal carcinoma. The New England journal of medicine 333: 693-698.

8. Umeora OU, Onuh SO (2007) Cancer of the Cervix at the University of Benin Teaching Hospital (UBTH), Benin City, Nigeria, in the last decade of the last Millennium. Orient Journal of Medicine 19: 24-30.

9. Gharoro EP, Abedi HO, Okpere EE (1988) Carcinoma of the cervix: aspects of clinical presentation and management in Benin City. Int J Gynaecol Obstet 26: 265-269.

10. Wang D, Liebowitz D, Kieff E (1985) An EBV membrane protein expressed in immortalized lymphocytes transforms established rodent cells. Cell 43: 831-

11. Wei W, Sham J (2005) Nasopharyngeal carcinoma. Lancet 365: 2041-2054. 